Research, part of a Special Feature on The Recent History and Practice of Local Fisheries in a Globalizing World

\title{
A Short History of the Namibian Hake Fishery-a Social-Ecological Analysis
}

\author{
Barbara Paterson $^{1}$, Carola Kirchner ${ }^{2,3}$ and Rosemary E. Ommer ${ }^{4}$
}

\begin{abstract}
As a legacy of Namibia's colonial past, the country inherited severely depleted fish resources at the time of independence. Today, Namibia's fisheries are almost exclusively industrial. The hake fishery is the country's most important fishery, which was restructured from a pre-independence foreign fishery into one that is characterized by locally based, vertically integrated fishing and processing companies. It is widely believed that Namibia has successfully combined the neoliberal economics that have been characteristic of the development narratives since the 1980s with welfarist goals for poverty reduction. However, there are strong indications that the fish stocks are declining, while the high economic expectations for the fishery have not been fulfilled. Rather, it seems that the Namibian government's attempt to combine economic neoliberalism and social equity has, in fact, created a developmental dilemma. We track the environmental impact of the historic exploitation of Namibia's fish resources and examine this dilemma and its effects on Namibia's fisheries management.
\end{abstract}

Key Words: distant water fleets; fisheries; hake; Merlucius capensis; Merluccius paradoxus; Namibia; Namibianisation; Northern Benguela; South West Africa; sustainable fisheries development

\section{INTRODUCTION}

Namibia's Marine Resources Act of 2000 has been celebrated internationally as one of the most progressive and successful fisheries policies, earning Namibia the Food Security Policy Leadership Award in 2010 and the Silver Future Award in 2012. Fisheries are considered to be an important basis for economic growth and development in many countries (World Bank and FAO 2009). The Benguela Current large marine ecosystem is one of the most productive in the world, and Namibia's fishery resources have been of global importance for centuries. Unlike other fishing nations, Namibia's fisheries have not originated from local small-scale subsistence fisheries, but the country's marine resources have always been subject to foreign industrial-style exploitation. Thus, when Namibia gained independence in 1990, the state restructured the fisheries sector, aiming to direct the flow of benefits toward Namibians. Today, two species of hake-shallow-water hake (Merluccius capensis) and deepwater hake (M. paradoxus) are caught by demersal trawl and long-line vessels in Namibia's most important fishery. The hake fishery is almost exclusively export-based and industrial: in 2007, an estimated $97 \%$ was exported, mostly as fresh, chilled, or frozen raw material.

In line with neoliberal views of traditional fisheries economics (Béné et al. 2010), the Namibian government hoped that the economic rents and the employment created by the fisheries sector would help address the country's pressing poverty issues, although other measures had been implemented to redress existing inequities more directly through the country's Namibianisation policy, which aims to increase the involvement of Namibians in the fishery. In addition, the
Namibian Fish Consumption Trust had been put in place to provide Namibians with access to fish products at low prices to offset the potentially negative effects that an industry directed at global markets might otherwise have for local food security.

Thus, it seems that Namibia has successfully combined the neoliberal economics that have characterized the development narratives since the 1980s (Gore 2000) with welfarist goals for poverty reduction. This general belief is reflected in the awards that Namibia's fishery policy received from the Future Council and the Food Agriculture and Natural Resource Policy Analysis Network. However, as in other historical export-led fishery economies (see, for example, Ommer 1991), little value added has accrued domestically (Sherbourne 2010). This is particularly worrying given that there are strong indications that the fish stocks are declining (BCC 2011) without the fishery ever having managed to fulfill economic expectations (Sherbourne 2010).

Studies related to other economic sectors, such as agriculture (Kaapama 2007) and manufacturing (Winterfeldt 2007), have shown that the Namibian government's attempt to combine economic neoliberalism and social equity has, in fact, created a developmental dilemma. We examine this dilemma and its effects on Namibia's fisheries management.

\section{METHODS}

\section{Historical approach}

We present a brief marine environmental history of the exportbased Namibian fisheries from early exploitation to the present day, based on the historical literature, government documents,

\footnotetext{
${ }^{1}$ Marine Research Institute (Ma-Re), Zoology Department, University of Cape Town, South Africa, ${ }^{2}$ National Marine Information and Research Centre (NatMirc), Ministry of Fisheries and Marine Resources, Namibia, ${ }^{3}$ University of Cape Town, Graduate School of Business, South Africa, ${ }^{4}$ University of Victoria
} 
and some interview data. We then track the environmental impact of that exploitation and show how problems of overfishing inherited from the past continue to bedevil the present-day fishery, despite government efforts to establish a more socially, industrially, and environmentally sensitive management plan.

\section{RESULTS AND DISCUSSION}

\section{Early history}

The northern Benguela marine ecosystem off the inhospitable hyperarid coastline of Namibia has experienced large-scale foreign exploitation since the 18th century (Moorsom 1984, Roux and Shannon 2004). Indiscriminate whaling and sealing activities by North American and European vessels since then have resulted in the rapid depletion of marine mammal populations. As early as the 19th century, the southern right whale (Eubalaena australis) and Cape fur seal (Arctocephalus pusillus) populations were declining; by the early 20th century, the local breeding population of southern right whales had been eradicated, and Cape fur seal breeding populations had disappeared from many locations. With the decline of seals, economic exploitation shifted to guano, and the subsequent disturbance of seabird colonies in pursuit of what became the overextraction of that resource, led to the severe depletion of seabird populations by the end of the 19th century (Roux and Shannon 2004).

\section{South African exploitation}

From 1884 until 1914, Namibia was a colony of Germany. When this early colonial period ended with World War I, South Africa-itself a former British colony and member of the British Commonwealth-invaded and occupied what was then called South West Africa. The South African invasion led to the surrender of the German troops, and at the end of the war, the League of Nations gave the occupier full power of administration and legislation over the "territory" (December 17, 1920). When the United Nations superseded the League of Nations in 1946, South Africa refused to surrender the mandate it had held for 26 years, and during its continued occupation of Namibia, introduced South African apartheid laws. It was not until 1988 that South Africa finally ceased to hinder Namibia's liberation process, and the country formally gained independence in March 1990.

During the period of occupation, the South African government had never completely integrated South West Africa into the state but administered it as a de facto province, exploiting Namibia's natural resources and giving its white minority representation in the whites-only Parliament of South Africa. During this time, the South African rock lobster (Jasus lalandii) fisheries gradually extended northwards to take advantage of the rich fishing grounds off the Namibian coast, at the same time as depletion of local lobster beds through overfishing caused a northward shift of "the crayfish frontier" up the west coast and into South West Africa (van Sittert $1993 a, b)$. A Luderitz-based fishery for rock lobster developed in the 1930s (Moorsom 1984, van Sittert 1993a), peaked in the early $1950 \mathrm{~s}$ when approximately 14,000 tonnes were landed, and then collapsed. Today, the fishable biomass of rock lobster is less than 1000 tonnes, recruitment is below average, and there is no sign of recovery.

Fisheries for small pelagic fish, sardines (Sardinops sagax), and anchovy (Engraulis encrasicolus) started in the 1940s on the west coast of South Africa. The existence of an abundance of small pelagic fish off the Namibian coast caused South African companies to jockey for fishing licenses in what was then the South West African territory, and catch rates in the colony soon outstripped those at home. Due to the extreme weakness of local Namibian capital formation, coupled with the preferential issuance of licenses to mostly Afrikaanerowned companies, the small pelagic fishery was effectively a South African preserve (Moorsom 1984).

As processing and catching capacity in Walvis Bay grew, so did the demand for more fish, and companies continuously pressured the authorities into increasing catch quotas. Walvis Bay grew into the second biggest town in what was then South West Africa. The contract migrant labor system, an integral part of the apartheid economy, provided an unlimited supply of unskilled workers for the fishery.

In the mid-1960s, several South African companies persuaded the South African government to grant licenses for factory ships operating out of Cape Town, thus successfully bypassing the licence and quota restrictions put in place by the local administration in Windhoek (Moorsom 1984). In 1968, however, a 90,000 tonne pilchard quota was given to a consortium of hake licensees who were not part of the South African cartel. This was a deliberate investment that sought to develop a Walvis Bay-based hake sector. Under its new name, this company is now considered to be one of the few truly Namibian hake fishing companies.

That same year, landings of small pelagic fish peaked at about 1.5 million tonnes but declined rapidly thereafter (Fig. 1). In 1977, the small pelagics fishery, like the overexploited whales, seals, seabirds, and rock lobster before it, also collapsed.

Last to be fished were the offshore species, such as horse mackerel (Trachurus trachurus capensis) and the hakes because local demand for fresh and frozen hake for human consumption was limited in both Namibia and South Africa. South African trawler companies were therefore able to meet their requirement for raw product from home waters. As a result, Namibian-based trawling and processing remained on a small scale until the late 1960s, although after World War II, the foremost South African trawler company maintained a marketing monopoly over hake processed in Namibia. The collapse of the small pelagic fishery, coupled with the fact that 
Fig. 1. Reported landings by key fisheries, 1947-2011.

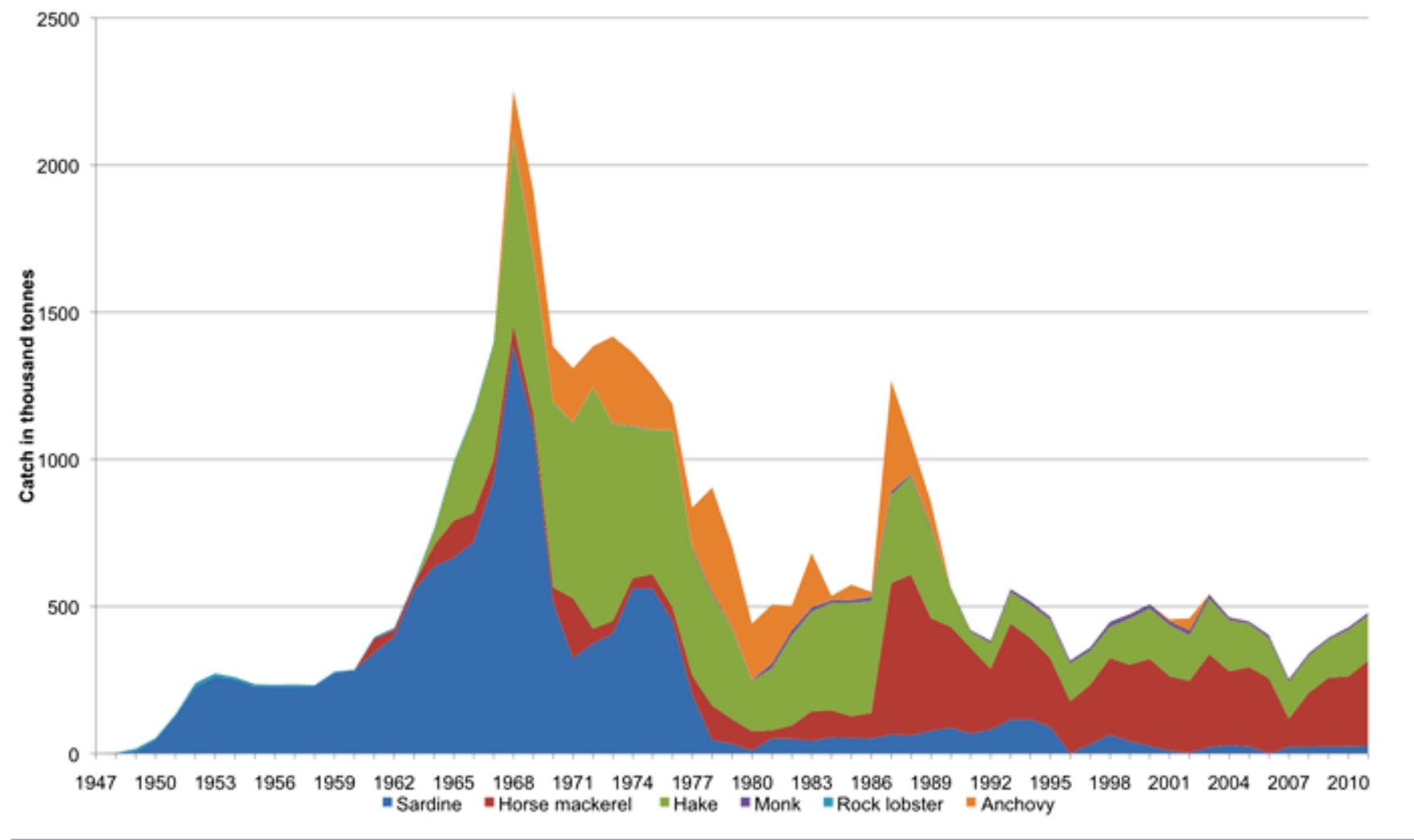

the South African hake fishery was fully exploited by the 1980s, led to a modest expansion of the Namibian-based trawl sector at that time. Most of the trawlers, however, belonged to South African companies, and the bulk of the catch was landed in South African ports (Moorsom 1984).

\section{Distant water fleets}

While Namibian- and South African-based interests were slow to develop a deep-sea trawl sector, the 1960s saw a sudden boom in foreign distant water fishing fleets in Namibian waters. This was part of a general expansion of distant water fleets brought about by the technological development of the factory freezer trawler (Ommer 2007:57-58). Large freezer vessels made long-distance fishing for human consumption in global markets both practical and economic, and by the mid-1960s, about 100 trawlers from foreign fishing nations (mainly European and Eastern Bloc countries) had begun to fish for hake and adult horse mackerel in Namibian waters. Between 1968 and 1972, Soviet and Spanish fleets caught significant amounts of hake, amounting to about $90 \%$ of the hake catches of all foreign fleets off the Namibian coast. The rapid increase in catches peaked in 1972 at more than 800,000 tonnes (Fig. 1) and was followed by an equally rapid decline.
It is possible that biased reporting of catches and efforts played a major role in the decline of hake stocks in Namibian waters (Roux and Shannon 2004), since the foreign fishing effort in the southeast Atlantic remained essentially unregulated until 1972. Although the International Commission for South East Atlantic Fisheries (ICSEAF) was formed in 1969, its first working session was not held until April 1972. Modeled on the International Convention for North Atlantic Fisheries, the ICSEAF was intended to be a forum in which scientific advice could be pooled and agreement on regulatory measures could be established. However, Namibian interests were not represented in the convention: the United Nations Council for Namibia was not a member of ICSEAF, while South Africa had the same status as the other 16 members. Indeed, the ICSEAF was essentially "an open-ended club of foreign states whose trawlers exploit Namibia's offshore waters" (Moorsom 1984). Its attempts to implement management measures, such as minimum mesh size (1975) and total allowable catches (TACs) (1977-1989), failed (Roux and Shannon 2004).

By 1979, both of Namibia's neighboring states, Angola and South Africa, had declared 200-mile (322-km) exclusive economic zones (EEZ). However, attempts by the South African administration to put into effect an EEZ along the 
Namibian coast were considered illegal by the foreign fishing nations because South Africa's mandate over Namibia had been revoked by the United Nations. As neither the South West Africa administration nor the South African navy enforced the fishery zone (Moorsom 1984), the EEZ was ignored, and Namibian waters were destined to remain essentially an unregulated open-access area until Namibia's independence in 1990.

By 1980, the hake population had been reduced to less than $50 \%$ of its former size, and catch per unit effort had declined by $60 \%$. Over the same period, fishing effort had doubled (Moorsom 1984). By this time, all foreign fleets except the Spanish were fishing hake only intermittently, having shifted their attention to horse mackerel instead. As with hake, so with horse mackerel: reported catches, which had been low in the 1960 s, increased in the 1970s and peaked in the 1980s at almost 600,000 tonnes. Since the early 1990s, even after Namibian independence, catch rates have steadily decreased to an average of 300,000 tonnes per year at present, mainly due to lower fish abundances (Roux and Shannon 2004).

\section{The recent past}

The pillaging of Namibia's fish resources by South African companies and distant water fleets has had severe consequences for the marine biophysical system. It has also brought very few benefits to Namibia's economy and people because profits from the fisheries have all been channeled out of the country (Moorsom 1984). It is thus hardly surprising that after independence, the Namibian government sought to restructure Namibia's fishing industry in such a way as to rebuild the hake stocks and generate maximum benefits from the resource for Namibians. In 1990, therefore, to remove foreign fishing effort from offshore waters, the Ministry of Fisheries and Marine Resources (MFMR) of Namibia declared a 200-mile (322-km) EEZ (MFMR 1990). A new fisheries institute was created, and Namibian scientists were recruited from other government departments. A new research program involving regular "at sea" surveys was put in place with Norwegian funding. Based on the high catch rates of previous decades, it was estimated that after a short period of recovery, the hake stocks would support long-term sustainable catch levels of 250,000-300,000 tonnes (MFMR 1991, as cited in Sherbourne 2010). In order to take maximum advantage of the anticipated yields, the government encouraged the rapid development of both a local fishing fleet and onshore processing facilities. In the absence of a local small-scale fisheries sector, the way was open for the development of a vertically integrated fisheries sector. Due to the shortage of Namibian capital, the country took a general "policy decision to embark on an export driven industrialization" (Republic of Namibia 1995, as cited in Winterfeldt 2007). Thus, the same foreign fishing nations that had been barred from fishing in Namibia's waters were now invited back, as capital investors, to help develop an export-based fishing industry in Namibia.
This newly created industry initially enjoyed real growth rates but thereafter stagnated and declined (Sherbourne 2010).

The period of Namibia's transition into independence was characterized by the global rise of the neoliberal governance model, which became an important condition for the acquisition of international development aid (Kapaama 2007) and influenced fisheries economics worldwide. The Namibian government's goal was to create a profitable fishing industry and increase foreign earnings from exported fish. In addition, the state introduced the so-called "Namibianisation policy" to facilitate greater involvement of Namibians in the sector and greater benefits for them from the sector (Erastus 2002). The policy was designed to motivate Namibians to participate in the fishing industry, either as owners or as employees (Armstrong et al. 2004). This was to be done using two strategies. The first was designed to increase direct control over the fishery via Namibian majority shareholding in fishing companies and to increase economic benefits to Namibians through job creation; the second was intended to generate earnings and revenue for government, which would then allow government to improve the lot of Namibians in a number of ways (Erastus 2002).

Namibian government policies started well enough. In 1990, catch limits were drastically reduced to 60,000 tonnes "to allow the stock to recover" (MFMR 2004). However, this reduction in catch limits was contested by scientists outside Namibia. In particular, the "scientists involved in the management of the fishery on an advisory basis for ICSEAF were stunned by the conservativism [sic] of the initial TAC recommendation by the new government" (Olrac 2013). In Namibia, government scientific recommendations are presented to both the Minister and the Marine Advisory Council. The latter is composed of two representatives of the MFMR, five representatives of the fishing industry, and six representatives of other economic sectors, including banking, who jointly take cognizance of social and economic considerations (although their criteria for social and economic considerations are neither explicit nor transparent) and then formulate their own recommendations for the Minister. As a result, industrial and financial neoliberal thinking was injected into the process, and pressure was put on the government to increase catch limits.

The government did this slowly, raising catch limits to 120,000 tonnes in 1997. At the same time, the survey-based biomass estimates and the catch data dropped markedly (Butterworth and Geromont 2001). Namibian scientists thus recommended returning to the initial low catch levels, but a second group of scientists, who had been hired by the industry, contested this decision. Consequently, on the strength of the high catch levels of the past and the consequent high expectations regarding the productivity of the resource (Sherbourne 2010), the Namibian government continued to increase catch levels (Fig. 1). 
Scientists hired by the industry encouraged the government in this decision by pleading their case "in writing and verbally to meetings of the Namibian Fisheries Advisory Committee. The result has been that the crippling TAC reductions proposed by some of the scientists have not been implemented" (OLRAC 2013).

As a result, since 1993, and despite the exceedingly low biomass, the government TAC has been higher than that recommended by government scientists (Table 1). In 1999, it reached 210,000 tonnes, even though the average annual catch over the whole period from 1950 to 1999 was only about 148,000 tonnes (Fig. 1). Indeed, throughout the whole period, government TACs consistently exceeded both annual catch rates and scientific recommendations (Table 1). The 2012 approved management plan for Namibian hake seeks to rebuild the resource to 1990 levels (MFMR 2012), even though that is when the newly nationalized stocks were at an all-time low.

Table 1. Scientifically recommended total allowable catch (TAC), allocated total allowable catch, and catch, in 1000 tonnes. Data provided by the Ministry of Fisheries and Marine Resources (MFMR) of Namibia.

\begin{tabular}{cccc}
\hline \hline & $\begin{array}{c}\text { Recommended } \\
\text { TAC }\end{array}$ & $\begin{array}{c}\text { Allocated } \\
\text { TAC }\end{array}$ & Catch \\
\hline 1990 & & 60 & 132 \\
1991 & 100 & 60 & 56 \\
1992 & 60 & 90 & 87 \\
1993 & 120 & 120 & 108 \\
1994 & 130 & 150 & 112 \\
1995 & 120 & 150 & 130 \\
1996 & 62 & 170 & 129 \\
1997 & 50 & 120 & 117 \\
1998 & 140 & 150 & 107 \\
1999 & 210 & 210 & 158 \\
2000 & 194 & 194 & 171 \\
2001 & 200 & 200 & 174 \\
2002 & & 195 & 156 \\
2003 & 176 & 180 & 189 \\
2004 & 158 & 196 & 174 \\
2005 & 160 & 180 & 141 \\
2006 & 140 & 130 & 137 \\
2007 & 130 & 130 & 126 \\
2008 & 120 & 130 & 126 \\
2009 & 110 & 148 & 130 \\
2010 & 100 & 140 & 159 \\
2011 & 145 & 180 & 154 \\
\hline & & & \\
\hline & & & \\
\hline
\end{tabular}

\section{The current situation}

Export-led growth has been successful in many places but always through the capture of staple export-related linkages, such as value added to the staple product (a "forward linkage"), transportation and other infrastructure ("backward linkages"), and increased wages for workers, which would increase their capacity to spend and thus increase local demand (final demand linkage), thereby stimulating other domestic industries and businesses that would, over time, allow the country to move from export dependence to an internally independent developed economy.

Namibian fishing policies might have helped such an exportled path to development. However, the neoliberal model that the Marine Advisory Council and others follows emphasizes growth and corporate profits, whose benefits are then to trickle down to the domestic economy through job enhancement. This path privileges corporate wealth over the creation of broader local development and thus inhibits linkage formation (see Ommer [1991:190-191] for a discussion of staple-led development, and Harvey [2005] for a discussion of how neoliberal insistence on rapid growth inhibited local development). Namibia's most prominent policy document, Vision 2030, which was launched in 2004, continues the combination of "socioeconomic justice on a national scale with the merciless dictates of profitability emanating from global economic liberalism" (Winterfeldt 2007).

This difficult marriage is also reflected in the hake management plan, which promotes both economic efficiency and benefits for "a large number of Namibians" (MFMR 2012). To accelerate achievement of these benefits, a regulation was put in place in 2000 that required existing, mainly foreign-owned, companies to form joint ventures with Namibian "counterparts" in order to receive fishing rights. It has become clear, however, that this policy has effectively promoted the interests of a privileged black minority but fails to redress the "grossly inegalitarian social structure and distribution of wealth" (Melber 2003). It has long been apparent that the main interest of many of the local Namibian partners is to reap profits without reinvesting in the maintenance and purchase of assets (Melber 2003), thereby blocking domestic linkage development. It seems that this practice has now caused the closure of a prominent fish processing plant and the layoff of more than 700 workers (Hartman 2013). This represents a loss of forward and final demand linkages in the form of value-added processing and waged workers.

Namibia has a general unemployment rate of $51.2 \%$ (Sherbourne 2010) and is among the most unequal societies worldwide, with an extremely unequal distribution of income (Melber 2007). As many as 20\% of Namibians earn less than US $\$ 1$ per day (World Bank 2012). The lack of national wageearning employment opportunities means final demand remains low and provides no stimulus to the domestic economy. Indeed, poor households struggle to buy food. For rural people, this goes along with a high dependency on subsistence farming, which is characterized not only by low economic value (which would not necessarily be problematic 
if it were sustainable) but also by uncertain levels of food production, given Namibia's harsh climatic conditions.

Walvis Bay, with 61,000 inhabitants, is the largest coastal town (National Planning Commission 2011) and the industrial center of the fishing industry, and has a population of migrant workers that is increasing at the rate of $5.35 \%$ per annum (Batty et al. 2005). In 2004, only $20.9 \%$ of the heads of households were born in town, $45.6 \%$ were from rural areas, $32.7 \%$ were from other areas in Namibia, and $0.9 \%$ were from outside Namibia (Fig. 2). People from rural areas are attracted to Walvis Bay because of limited work opportunities elsewhere, and because people perceive that there is an availability of employment in the Walvis Bay mining and fishing industries. Although it is seen as an employment hub, the area possesses a continuously growing township of migrants, and is characterized by significant pressure on water, electricity, and housing supplies, resulting from a rapid in-migrant growth rate that far outstrips the actual need for labor. Lack of decent housing, inadequate access to food and health care, and a rising crime rate are just some of the poverty-related challenges that have resulted.

Fig. 2. Origin of heads of households in Walvis Bay, Namibia. Data adapted from Tapscott 1999.

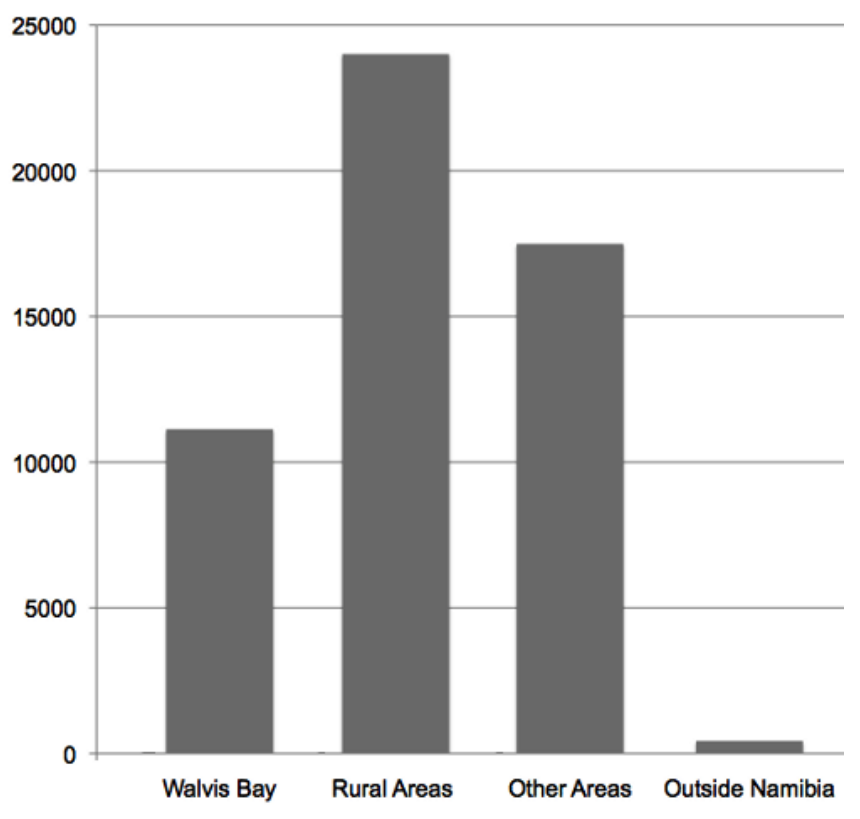

Research conducted in 2011 with workers from different hake processing plants in Walvis Bay brought to the surface serious issues of very low income levels, low job satisfaction, and very limited career opportunities (Paterson and Isaacs, unpublished manuscript). Not only is the workforce in the fish plants highly stratified along gender and racial lines, but most of the plant workers earn wages that are too low to meet the cost of urban living.

Furthermore, resource rents and revenues from hake fishing are far lower than Namibia expected in the 1990s (Sherbourne 2010). Added to that, the coupled effects of environmental variability and heavy fishing are leading to unforeseen trophic interactions, which suggest that the marine food web of the northern Benguela system may have been substantially altered in recent years (Roux and Shannon 2004). At the same time, the resource has sunk even further into depletion (BCC 2011, Kirchner et al. 2012).

Despite the lower catch rates, declining average fish sizes, and lower prices, and in the face of a major global economic downturn, the fishing industry still saw fit, in 2007-2008, to invest roughly N\$200 million in factories and fishing vessels (MFMR 2009, unpublished data). This belated attempt to capture backward linkages from the fishery was ill-fated from its inception, given that the state of the resource was such that it was totally unable to bear the additional exploitation that such linkage development implied. The upshot has been that the present-day hake industry has the capacity to catch and process 300,000 tonnes of fish per year, while actual landings were less than half that amount in 2009 (Sherbourne 2010). That is, a significant overcapacity problem has been created, which could have been avoided, given the evidence that was available to the industry at the time.

In short, the current exploitation of the Namibian hake resources is not only detrimental to the fish but seems also to be falling short of the social and economic goals that were intended in the Namibian policy. The first two decades of Namibian management have not been as successful as was hoped. In the first place, the resource has not recovered from the low stock abundance levels that were inherited at independence. Secondly, the joint venture agreements and proxy ownership arrangements (Sherbourne 2010) have benefited only an elite minority of Namibians, while foreign involvement in the hake fishery remains dominant. Thirdly, although the development of the onshore processing sector (a forward linkage) has been successful in the creation of jobs, given labor overcapacity and consequent very low wages, final demand has not taken place, and workers in the fishery remain extremely vulnerable. Indeed, some of that processing capacity has recently been lost.

Jauch (2007) has argued that although the interests of workers and peasants once constituted the dominant position of the ruling party, these working class politics have been pushed aside in the predominant industrial capitalist export-led economy. Jobs and employment statistics are certainly frequently used as leverage to gain access to fishing quota, and it is also the case that the interests of laborers in the fishing industry are at odds with the neoliberal regime of maximized industrial profitability. "Too weak is their position as an un- 
skilled workforce, too easily replaceable the individual employee, given the inexhaustible reservoir of internal labour migrants in an economy ruled by poverty" (Winterfeldt 2007). However, there is a real issue of the inability of the resource to withstand the kind of fishing pressure that is, in itself, putting pressure on both the industry and its workers. Indeed, the strong policy focus on job creation, designed to achieve the socioeconomic development goals of the nation, has actually led to the perverse situation that the fishing and processing capacity in the hake sector is twice the size of the TAC and landings.

The industry, having been encouraged by policy to invest in capacity, frequently uses excess capacity in the fleet and onshore processing facilities, coupled with claims of low profitability, as grounds for requesting that the TAC and individual quotas be increased. If not, they say that there will be an inevitable drop in employment in the sector. This threat has great leverage with government, and is one of the main reasons why the actual TAC is consistently higher than the scientifically recommended one. Moreover, the increased number of rights holders that resulted from the policy to provide resource access to previously disadvantaged Namibians also creates a demand for more quota. Added to this, the Minister is under no obligation to follow the advice of his Ministry's scientists. It is not surprising then, that in 2010, the actual TAC given by the Minister was $40 \%$ higher than the scientific recommendation (Table 1). A former member of the advisory council recounts the following:

And so, I think, with a threat of the people maybe
losing theirjobs and people being laid off and closing
down, and so on, the request was that please consider
an increase in the TAC (...) at the end of the day the
minister can accept the advisory council's
recommendation in full or a version between what
the scientists recommended and the council
recommended and what his resource management
team recommended. Or if he doesn't like it at all he
can make a decision on his own and go to cabinet
with that and get approval for TAC allocations.

\section{CONCLUSION}

Fisheries management decisions need to be both scientifically and socially driven (Ommer 2007), and the appropriate model needs to be applied when adopting economic strategies for national policy. Although Namibia's fisheries policy has been celebrated for achieving both the goals of being scientific and socially sensitive, this is only superficially true. The ecological, economic, and social realities around Namibia's fisheries management are not sustainable. The dominant "bioeconomic" model of mainstream fisheries management assumes that the neoliberal economic model of "trickle down" growth can be harnessed to prevent overexploitation of resources, which is manifestly incorrect in this case. Moreover, the marrying of that model to the application of an expert-led growth approach has not been sensitive to the circumstances under which export-led growth will function appropriately. The Namibian example documents how injecting the search for final demand linkages in the guise of a welfarist slant into an otherwise neoliberal wealth-based management approach is not only inadequate but has created a management dilemma where social, economic, and ecological goals are in conflict on the political stage.

Namibian fisheries management should not be at odds with either the biological functioning of the hake stocks in the context of an altered ecosystem or the economic development needs of the nation, including the employment welfare of the people in the export sector. The 2012 hake management plan recommends that stock assessments need to assume that the ecosystem has changed and that new target and reference points that are based on the new productivity regime need to be set (MFMR 2012). From an ecological perspective, this is encouraging. However, as recent Namibian history has shown, sound science alone is not enough to guarantee a healthy fishery. Unless the ecological, economic, social, and political factors at play are considered together, the chances for successful rebuilding of the hake stocks and the direction of the flow of benefits towards the socioeconomic uplifting of the majority of Namibians are minimal.

The question of appropriate scale of management and data acquisition are also of real importance in the social and economic context of Namibian fisheries. The MFMR compiles and monitors statistics at the level of the company and the rights holder. But much more detailed quantitative and qualitative data need to be acquired, with respect to not only the ecological but also the social and political aspects of the fisheries. Fisheries management needs to take into account what is happening socially, at the company, household, and individual level, in order to determine who benefits and who loses from management decisions. Employment statistics do not tell the whole, or even the real, story. The current policy focus on increasing the number of jobs and "paper" rights holders without any critical analysis of the situation created by these policies engenders a vicious circle of overcapitalization, need for more fish, consequent damage to stocks, and ultimate risk of yet another stock collapse, with most of that risk falling on not just the fish but also the already vulnerable poor.

As long as the larger political economy of the country is such that important decisions regarding resource access and the rights for exploitation are made without transparency, without the appropriate application of approaches to linkage development and export-led growth, and without reliable data, the social, economic, and ecological objectives for the hake fishery will not be achieved, no matter how well intended the policies of the government may be. 
Responses to this article can be read online at: http://www.ecologyandsociety.org/issues/responses. $\mathrm{php} / 5919$

\section{Acknowledgments:}

This article was written as part of ECOFISH, which is a project of the Benguela Current Commission, the Technical University of Denmark, and the University of Cape Town. Fieldwork in Namibia was supported also by the South African research chair in marine ecology and fisheries, the international science and technology agreement between South Africa and Namibia, and the African research project on knowledge production under the University of Cape Town's Programme for the Enhancement of Research Capacity (PERC). Thanks to Astrid Jarre for support and to Kelsey Draper, Lelsey Green, and Barb Neis for valuable discussions.

\section{LITERATURE CITED}

Armstrong, C. M., U. R. Sumaila, A. N. Erastus, and O. Msiska. 2004. Benefits and costs of the Namibinisation policy. Pages 203-215 in U. R. Sumaila, D. Boyer, M. D. Skogen, and S. I. Steinshamn, editors. Namibia's fisheries: ecological, economic and social aspects. Eburon, Delft, The Netherlands.

Batty, M., M. Tjipute, and M. Shapi. 2005. Overview and analysis of social, economic and fisheries information to promote artisanal fisheries management in the BCLME region, Namibia. Final Report and recommendations. Unpublished report. Benguela Current Commission.

Béné, C., B. Hersoug, and E. H. Allison. 2010. Not by rent alone: analysing the pro-poor functions of small-scale fisheries in developing countries. Development Policy Review 28(3):325-358. $\quad$ http://dx.doi.org/http://dx.doi.org/10.1111/ j.1467-7679.2010.00486.x

Benguela Current Commission (BCC). 2011. Benguela Current large marine ecosystem annual state of fish stocks report. Benguela Current Commission.

Butterworth, D. S., and H. F. Geromont. 2001. Evaluation of a class of possible interim management procedures for the Namibian hake fishery. South African Journal of Marine Science 23:357-374. http://dx.doi.org/10.2989/025776101784528962

Erastus, A. N. 2002. The development of the Namibianisation policy in the hake subsector, 1994-1999. NEPRU Working Paper No. 82, Windhoek, Namibia.

Gore, C. 2000. The rise and fall of the Washington consensus as a paradigm for developing countries. World Development
28(5):789-804. http://dx.doi.org/10.1016/S0305-750X(99) $\underline{00160-6}$

Harvey, D. 2005.A brief history of neoliberalism. Oxford University Press, New York, New York, USA.

Jauch, H. 2007. Between politics and the shop floor. Which way for Namibia's labour movement? Pages 50-64 in $\mathrm{H}$. Melber, editor. Transitions in Namibia which changes for whom? Nordiska Afrikainstitutet. Elanders Gotab AB, Stockholm, Sweden.

Kaapama, P. 2007. Commercial land reforms in postcolonial Namibia. What happened to liberation struggle rhetoric? Pages 29-49 in H. Melber, editor. Transitions in Namibia which changes for whom? Nordiska Afrikainstitutet. Elanders Gotab AB, Stockholm, Sweden.

Kirchner, C. H., P. Kainge, and J. Kathena 2012. Evaluation of the status of the Namibian hake resource (Merluccius spp.) using statistical catch-at-age analysis. Environment for Development. EFD DP 12.12.

Melber, H. 2003. Of big fish \& small fry: the fishing industry in Namibia. Review of African Political Economy 30(95):142149.

Ministry of Fisheries and Marine Resources (MFMR). 1990. Territorial sea and exclusive economic zone of Namibia. (Act No. 3 of 1990). Government Gazette, Republic of Namibia.

Ministry of Fisheries and Marine Resources (MFMR). 1991. Towards responsible development of the fisheries sector. Ministry of Fisheries and Marine Resources, Windhoek, Namibia.

Ministry of Fisheries and Marine Resources (MFMR). 2004. Namibia's marine resources policy. Towards responsible development and management of the marine resources sector. Ministry of Fisheries and Marine Resources, Windhoek, Namibia.

Ministry of Fisheries and Marine Resources (MFMR). 2012. Management plan for the Namibian hake fishery. Ministry of Fisheries and Marine Resources, Windhoek, Namibia.

Moorsom, R. 1984. Exploiting the sea. A future for Namibia 5. Fishing. Catholic Institute for International Relations, London, UK.

National Planning Commission. 2011. Namibia 2011 national population and housing census. Preliminary results. [online] URL: http://www.gov.na/documents/10180/34849/2011 Preliminary_Result.pdf/0ea026d4-9687-4851-a693-1b97a1317c60

OLRAC. 2013. The Namibian hake fishery (M. paradoxus and M. capensis). [online] URL: http://www.olrac.com/index. 
php?option $=$ com $\_$content $\&$ view $=$ article $\&$ id $=120$ :the-namibianhake-fishery-m-paradoxus-and-m-capensis \&catid=53: projects\&Itemid=152" target=" blank">http://www.olrac.com/ index.php?option=com content \&vview=article\&id=120:thenamibian-hake-fishery-m-paradoxus-and-m-capensis\&catid=53: projects\&Itemid $=152$

Ommer, R. E. 1991. From outport to outport: a structural analysis of the Jersey-Gaspé cod fishery, 1767-1886. McGillQueen's Press.

Ommer, R. E. 2007. Coasts under stress. Restructuring and social-ecological health. McGill-Queen's University Press, Montreal, Quebec, Canada.

Republic of Namibia. 1995. Government of Ministry of Trade and Industry: EPZ business plan for proposed offshore development company. Windhoek, Namibia.

Roux, J.-P., and L. J. Shannon. 2004. Ecosystem approach to fisheries management in the northern Benguela: the Namibian experience. African Journal of Marine Science 26(1):79-93. http://dx.doi.org/10.2989/18142320409504051

Sherbourne, R. 2010. Guide to the Namibian economy. Institute for Public Policy Research, Windhoek, Namibia.

Tapscott, C. 1999. An overview of the socio-economics of some key maritime industries in the Benguela Current region. Report prepared on behalf of the Benguela Current Large Marine Ecosystem Project.

van Sittert, L. 1993a. "More in the breach than in the observance": crayfish, conservation \& capitalism c. 1890-c. 1939. Environmental History Review 17(4):20-46.

van Sittert, L. 1993b. 'Making like America': the industrialisation of the St Helena Bay fisheries c. 1936-c. 1956. Journal of Southern African Studies 19(3):422-446. http://dx.doi.org/http://dx.doi.org/10.1080/03057079308708368

Winterfeldt, V. 2007. Liberated economy? The case of Ramatex Textiles Namibia. Pages 65-93 in H. Melber, editor. Transitions in Namibia. Which changes for whom? Nordiska Afrikainstitutet. Elanders Gotab AB, Stockholm, Sweden.

World Bank. 2012. Namibia country brief. http://dx.doi. org/10.1596/978-0-8213-7870-0

World Bank, and Food and Agriculture Organization of the United Nations (FAO). 2009. The sunken billions: the economic justification for fisheries reform. World Bank, Washington, D.C., USA. 